\title{
Municipal-Aboriginal Relations: An Ontario Perspective
}

Commonwealth Journal of Local Governance

Issue 3: May 2009

http://epress.lib.uts.edu.au/ojs/index.php/cjlg

\author{
Alia Hanif, Ruth Melady, Donna Simmonds, Ralph Walton \\ The Ministry of Municipal Affairs and Housing - Ontario, Canada
}

Key words: municipal, Aboriginal relationships, Aboriginal communities, engagement, consultation, Ontario

\section{Introduction}

In Canada, there are many examples of respectful relationships between municipalities and Aboriginal communities. Where Aboriginal peoples have concerns with the actions or inaction of governments (be they federal, provincial or municipal governments), it is often municipalities that are directly affected by the measures taken by Aboriginal peoples to express their concerns. To help reduce possible conflicts at the municipal level and find shared solutions, the Ministry of Municipal Affairs and Housing of the Province of Ontario has been advising municipalities in the province on the benefits of engaging and developing relationships with Aboriginal peoples.

This report explores, from the perspective of Ontario's Ministry of Municipal Affairs and Housing, the benefits of municipal engagement with Aboriginal communities. It provides an overview of Aboriginal and treaty rights, ${ }^{1}$ the constitutional duty to consult, the value in developing constructive municipal-Aboriginal relationships, and examples from Ontario that illustrate how these relationships benefited both communities.

${ }^{1}$ Aboriginal rights stem from practices, customs or traditions integral to the distinctive culture of each Aboriginal community, such as hunting and fishing. Treaty rights stem from the signing of treaties entered into between Aboriginal people and the Crown. 


\section{The Constitutional Context and Duty to Consult}

Canada is a federal system of government sharing the Crown's constitutional roles with ten provinces and three territories. Canada's Constitution Act, 1982 defines Aboriginal peoples to include Indian, Inuit and Métis people of Canada, and recognizes and affirms their Aboriginal or treaty rights (Department of Justice Canada, 1982). The Supreme Court of Canada has clarified this recognition and affirmation, including the protection of rights which have been asserted, and that federal and provincial governments have a duty to consult when considering decisions that may adversely affect Aboriginal or treaty rights. ${ }^{2}$ While the court has clarified that the Crown (the federal and provincial or territorial governments) has a duty to consult in some circumstances, the court has not pronounced upon municipalities' duty to consult.

In Ontario, Canada's most populous province, municipalities have authority pursuant to various provincial statutes, which may, if acted upon, affect Aboriginal and treaty rights. For example, municipalities are responsible for many land use decisions that have the potential to impinge on Aboriginal or treaty rights. In some circumstances, the municipal approach to such matters is negatively affected by uncertainty about the municipal role in the duty to consult Aboriginal peoples. While there is a lack of clarity regarding this matter, it is the position of Ontario's Ministry of Municipal Affairs and Housing that there are some circumstances in which municipalities have a duty to consult Aboriginal communities. Ontario's Ministry of Municipal Affairs and Housing has been advising municipalities that there are benefits to engaging and developing relationships with Aboriginal peoples, in a manner that goes beyond possible legal requirements related to the duty to consult.

\section{Opportunities for Engagement}

Municipalities and Aboriginal communities engaging each other on shared interests and initiatives are likely to experience greater benefits than those limiting their interaction to the narrow matters in which a legal duty to consult may arise. Limiting engagement to those

\footnotetext{
${ }^{2}$ Haida Nation v. British Columbia (Minister of Forests), 2004 SCC 73 (Can LII) http://www.canlii.org/eliisa/highlight.do?language=en\&searchTitle=Search+all+CanLII+Databases\&path=/en/ca/scc/doc/2004/2004scc7 3/2004scc73.html; Taku River Tlingit First Nation v. British Columbia (Project Assessment Director), 2004 SCC 74 (Can LII) http://www.canlii.org/eliisa/highlight.do?language=en\&searchTitle=Search+all+CanLII+Databases\&path=/en/ca/scc/doc/2004/2004scc7 4/2004scc74.html; Mikisew Cree First Nation v. Canada (Minister of Canadian Heritage), 2005 SCC 69 (Can LII) http://www.canlii.org/eliisa/highlight.do?language=en\&searchTitle=Search+all+CanLII+Databases\&path=/en/ca/scc/doc $/ 2005 / 2005 \mathrm{scc} 6$ $\underline{9 / 2005 \operatorname{scc} 69 . h t m l}$
} 
circumstances where a legal duty to consult may be triggered could potentially result in missed opportunities to develop relationships and experience joint success on shared community projects. Focusing only on possible requirements around the duty to consult could result in interactions being limited to circumstances involving statutory time lines and may be perceived as win-lose, which might lead to increased tensions between the communities and diminished appreciation for others' perspectives.

There are a number of municipalities in Ontario that are choosing to focus on engaging their Aboriginal neighbours outside of the legal and constitutional framework. Increasingly, these neighbouring communities are recognizing that it makes good business sense to work together on many different issues, not just where there are potential legal requirements. Meaningful and regular municipal-Aboriginal engagement and relationship-building can help balance interests and achieve common objectives in a number of ways:

- Identify areas of mutual interest and develop joint initiatives;

- Meet regulatory requirements for community development;

- Partner on service delivery and resource management;

- Increase cultural development and youth retention.

\section{Examples Across Ontario}

Across Canada, there are a number of successful examples of communities that have engaged with Aboriginal communities on broad interests and initiatives, rather than limiting their interactions to the narrow matters in which a duty to consult may arise. The following examples highlight some experiences in Ontario. The unique experiences of each municipality and local Aboriginal community play a defining role in

Figure 1: Lessons in Future Relations Building Opportunities

- Communities joining together to tackle shared issues are likely to find mutually beneficial solutions and new opportunities for collaboration

- Commitment by local leadership is important to initiate and continue successful relationships

- Relationships will develop and evolve as the parties gain experience in sharing

- Good relationships are particularly important in circumstance of divergent interests. 
shaping these engagements and developing innovative ways to work together to address local issues and needs. These examples provide broad lessons to guide future relationship building opportunities (see Figure 1).

\section{Common Ground Working Group - City of Kenora and Grand Council of Treaty \#3}

In 2001, the leaders of the Grand Council of Treaty \#3 in north-western Ontario and the City of Kenora created the Common Land, Common Ground initiative as a forum in which the First Nations and the municipal government could discuss areas of mutual concern. The communities recognized that this initiative would assist in creating and maintaining ways to live and work cooperatively, while building constructive relationships that could assist in avoiding potential disputes regarding their shared interest in local lands and resources.

The discovery in the City of Kenora of the Rat Portage, a key link in the historic, transCanada canoe route used by Aboriginal peoples, was an opportunity for the Common Land, Common Ground forum to address and resolve a potentially divisive situation. The result was that the City of Kenora and the First Nations were able to develop a shared management approach to protect the site.

The success of the Rat Portage agreement laid the groundwork for the development of another collaborative management agreement. Tunnel Island was the site of a mill that was closing and the private owners were divesting itself of its holdings, including 370 acres of land on Tunnel Island. Elders and leaders from the First Nations worked with municipal leaders and representatives of the private company to develop a common vision and shared principles to guide the treatment of the island. This partnership, one of alliance and sharing between peoples, reflected the intent of the original Crown and First Nations treaty, and resulted in the transfer of the land from the private company to a joint Aboriginal-municipal management team. 


\section{Serpent River First Nation and the City of Elliot Lake - Memorandum of Understanding}

While these neighbouring communities had a history of ad hoc relationships based on immediate need, there was recognition of the need for long-term collaboration between municipal and Aboriginal communities. The parties created a Joint Relations Committee (JRC) with membership from the Serpent River First Nation (also known as the Anishinabek of Genaabaiging) and the City of Elliot Lake. The JRC provides information, options and recommendations to their respective councils.

Both parties recognize that rebuilding the economy of the area depends on collaboration and maintaining a strong relationship. They developed a formal Memorandum of Understanding (MOU) that provides dispute resolution processes and focuses on five key priorities, which may be updated as needed:

- Economy / employment / procurement

- Heritage planning and sharing of resources

- Mutually beneficial supported initiatives, programs and services

- Land use and acquisition

- Joint lobbying and communications with other governments.

\section{Belle Island, City of Kingston}

Upon discovering human remains on the city property of Belle Island, the City of Kingston recognized the historical importance and registered portions of the island as a cemetery. Following an archaeological assessment of the site, the city council passed a resolution recognizing the First Nations interests in Belle Island. The city undertook consultations with First Nations with local and historical interests in the area regarding options to protect this historic site.

Based on advice from the participating First Nations, the city council approved a strategy to protect the site by establishing an implementation team including First Nations representatives; agreeing to retain responsibility for insurance, services and security; and 
creating a plan for future use to enhance the natural environment and preserve the dignity of the site.

The City of Kingston decided that it needed to address Aboriginal interests as part of its normal business practices. It committed to engaging with Aboriginal peoples by providing early notice and documentation of land use plans, and consulting with these groups on future projects in which they may have an interest.

\section{Conclusion}

Since 1982, the legal meaning of the constitutional protection given to Aboriginal and treaty rights in Canada has evolved and grown in significance. The duty to consult has arisen as a key element in the overall achievement of the protection of Aboriginal and treaty rights. The examples used here highlight Ontario municipalities that are choosing to build broader, positive relationships with Aboriginal communities, rather than relying purely on possible legal-based forms of engagement. Based on these experiences, municipalities have and continue to recognize the value of engaging and developing constructive relationships with Aboriginal peoples, not only when a divisive issue arises, but in everyday practice.

Ontario's Ministry of Municipal Affairs and Housing encourages the development and maintenance of strong relationships between municipalities and Aboriginal communities. The ministry encourages municipalities to work with Aboriginal peoples to recognize the important role they each have as contributors to the local economy, community health and the overall strength of both communities. In an environment of cultural and economic change, it is expected that there is more to be learned as both municipal and Aboriginal communities address local needs and interests on a collaborative basis.

\section{Acknowledgements}

The authors wish to thank the following people for either their previous support of this work or their advice throughout the development of this paper: Shane Gallagher, Karen Gautam, Peter Schmidt, Brian Walisser and Cathy Watson. 


\section{References}

Department of Justice Canada. "Part II Rights of the Aboriginal Peoples of Canada." The Constitution Act, 1982 [internet website]. Accessed 20 March 2009, $\langle$ http://laws.justice.gc.ca/en/const/annex_e.html\#II〉> 